\title{
High Affinity Interleukin-2 Receptor
}

National Cancer Institute

\section{Source}

National Cancer Institute. High Affinity Interleukin-2 Receptor. NCI Thesaurus. Code C38952.

Expressed on T- and B-cells, human heterodimeric High Affinity Interleukin-2 Receptor consists of IL2RA and IL2RB subunits, associated with a common IL2RG chain, and mediates IL2 mitogenic signaling. Homodimeric IL2RA chains constitute a low-affinity non-signaling receptor, while homodimeric IL2RB chains produce a medium-affinity signaling receptor. IL2RG comprises a signaling component of many interleukin receptors (IL2, IL4, IL7, IL9, and IL15). (NCI) 